\title{
HUKUM PELAKSANAAN SALAT JUMAT DUA GELOMBANG PADA SATU MASJID DI MASA PANDEMI COVID-19
}

\author{
Ronny Mahmuddin \\ Sekolah Tinggi Ilmu Islam dan Bahasa Arab (STIBA) Makassar \\ ronny.mahmuddin@stiba.ac.id \\ Fadhlan Akbar \\ Sekolah Tinggi Ilmu Islam dan Bahasa Arab (STIBA) Makassar \\ fadlanakbar75@gmail.com \\ Iskandar \\ Sekolah Tinggi Ilmu Islam dan Bahasa Arab (STIBA) Makassar \\ iskandarkato@stiba.ac.id
}

Keywords :
Law, Friday prayers, Two
Waves, Covid-19, Pandemic

Keywords

Waves, Covid-19, Pandemic
The condition of the corona virus pandemic (covid-19) in Indonesia has an impact on religious life for Muslims, such as Friday prayers. The government issued a regulation on Friday prayers at mosques in areas where the distribution of the prayers was controlled with a prayer distance of one meter to prevent the spread of the virus, resulting in the mosque being unable to accommodate many worshipers at a time. The purpose of this study is to describe the opinions of the scholars regarding the two waves of Friday prayer in one mosque and the Friday prayers in addition to the mosque during the Covid-19 pandemic, and also aims to respond to community questions about these two issues in order to find the right answers so that the community can perform worship calmly. This type of research is a qualitative descriptive study using a literature review method with a normative approach. The results of this study are that the scholars disagreed about the law of the two-wave Friday prayer in one mosque during the covid-19 pandemic. A strong opinion is that it is permissible to carry out two waves of Friday prayers in one mosque, due to emergency or urgent conditions such as the covid19 pandemic conditions, with the condition that the mosque is narrow and there is no other representative place to accommodate worshipers, the number of worshipers in the second wave is as much as the number of pilgrims in the first wave, as well as getting approval or permission from the government. The implementation of this research is expected to provide theoretical and practical contributions to scientists and society in general.

\footnotetext{
Kata kunci :

Hukum, Salat Jumat, Dua Gelombang, Covid-19, Pandemi.
}

\footnotetext{
Kondisi pandemi virus corona (Covid-19) di Indonesia membawa dampak terhadap kehidupan beragama bagi kaum muslimin, seperti pelaksanaan salat Jumat. Pemerintah mengeluarkan aturan pelaksanakan salat Jumat di masjid pada wilayah yang penyebaran covidnya terkendali dengan jarak saf salat satu meter untuk
} 
BUSTANUL FUQAHA: Jurnal Bidang Hukum Islam

Vol. 1, No. 3 (2020) : Hal. 350-365

Website: https://journal.stiba.ac.id

menghindari penyebaran virus, yang berakibat masjid tidak dapat menampung jemaah yang banyak dalam satu waktu. Tujuan kajian ini adalah untuk mendeskripsikan pendapat para ulama tentang hukum salat Jumat dua gelombang di satu masjid pada masa pandemi Covid-19, dan memilih pendapat yang rajih (kuat) pada kedua masalah ini; dan juga bertujuan untuk merespon pertanyaan masyarakat tentang kedua masalah ini agar ditemukan jawaban yang tepat sehingga masyarakat dapat melaksanakan ibadah dengan tenang. Jenis penelitian ini adalah penelitian deskriptif kualitatif dengan menggunakan metode telaah pustaka dengan pendekatan hukum-normatif. Hasil dari penelitian ini adalah bahwa para ulama berbeda pendapat tentang hukum salat Jumat dua gelombang di satu masjid pada masa pandemi covid-19. Pendapat yang kuat adalah diperbolehkan melaksanakan salat Jumat dua gelombang di satu masjid, karena kondisi darurat atau hajat yang mendesak seperti kondisi pandemi Covid-19, dengan syarat masjid sempit dan tidak ada tempat lain yang representatif menampung jamaah, jumlah jemaah di gelombang kedua sama banyaknya dengan jumlah jemaah di gelombang pertama, serta mendapatkan persetujuan atau izin dari pemerintah. Implementasi dari penelitian ini diharapkan memberikan konstribusi teoritis dan praktis bagi para ilmuan dan masyarakat secara umum. 


\section{PENDAHULUAN}

Islam diturunkan untuk memberikan kemaslahatan seluas-luasnya dan mencegah kemudaratan yang dapat menimpa umat manusia. Ada lima tujuan diturunkannya syariat Islam, yang disebut dengan Maqāsid al-Syarī'ah, yaitu untuk menjaga agama, melindungi jiwa, menjaga keturunan, melindungi harta dan menjaga kehormatan. Islam adalah agama yang mudah untuk dilaksanakan bagi pemeluknya, sebagaimana firman Allah dalam QS. al-Hajj/22: 78: "Kami tidak menjadikan agama ini (Islam) susah bagi kalian". Begitu pula firman-Nya dalam QS. al-Baqārah/2: 185: "Allah menginginkan bagi kalian kemudahan dan tidak menginginkan bagi kalian kesusahan". Sebagaimana pula sabda nabi saw: "Sesungguhnya agama Islam adalah agama yang mudah".

Dalam masalah ibadah begitu banyak kemudahan yang ada pada syariat Islam, tatkala seseorang sakit tidak bisa melaksanakan salat dalam keadaan berdiri, diperbolehkan baginya melaksanakan salat dalam keadaan duduk, dan jika tidak bisa duduk, maka diperbolehkan melaksanakan salat dalam keadaan terlentang. Begitu pula kemudahan dalam Islam pada ibadah taharah, tatkala seseorang sakit tidak bisa berwudu atau mandi janabah (wajib), maka diperbolehkan untuk tayamum. Kemudahan lainnya, tatkala seseorang dalam perjalanan jauh, maka diperbolehkan mengqasar dan menjamak salatnya. Bahkan ketika seseorang dalam keadaan yang sangat lapar dikhawatirkan bisa berujung kepada kematian, dan tidak ada makanan sedikit pun di tempat itu, melainkan hanya ada daging babi atau makanan yang diharamkan, maka diperbolehkan memakan daging babi tersebut secukupnya untuk menyelamatkan dirinya dari kematian.

Berkaitan dengan kondisi kita sekarang ini, kondisi merebaknya virus covid-19 di seluruh dunia termasuk di Indonesia, sehingga memberikan dampak kepada seluruh lini kehidupan termasuk kehidupan beragama atau beribadah bagi kaum muslimin seperti pelaksanaan salat Jumat. Pemerintah dan ulama telah mengeluarkan aturan akan bolehnya melaksanakan salat Jumat di masjid di daerah atau wilayah yang kondisi penyebaran covidnya terkendali, dengan syarat jaga jarak saf salat (physical distancing) satu meter untuk memutus mata rantai penyebaran covid-19. Aturan pemerintah dan ulama ini berdasar pada arahan dari para ahli medis, karena mereka yang lebih mengetahui tentang masalah wabah ini, sebagaimana firman Allah dalam QS. al-Nahl16: 43:

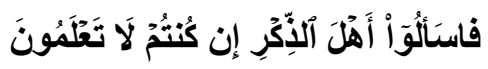

${ }^{1}$ Muhammad ibn Ismā’ìl al-Bukhāriy, Sahīh al-Bukhāriy, Vol. I (Dar Tuq al-Najah, 1422), h. 16. 
BUSTANUL FUQAHA: Jurnal Bidang Hukum Islam

Vol. 1, No. 3 (2020) : Hal. 350-365

Website: https://journal.stiba.ac.id

Terjemahan: Maka bertanyalah kepada orang yang mempunyai pengetahuan jika kamu tidak mengetahui.

Aturan ini tentu memberikan pengaruh yang begitu besar terhadap pelaksanaan ibadah salat Jumat yang biasanya dihadiri oleh orang. Namun, karena adanya aturan untuk menjaga jarak (physical distancing), maka saf-saf salat harus direnggangkan yang berakibat masjid tidak dapat menampung jemaah yang banyak dalam satu waktu, sehingga timbul pertanyaan terkait boleh atau tidaknya pelaksanaan salat Jumat dua kali di satu masjid karena kondisi darurat ini.

Berdasarkan permasalahan ini yang diperbincangkan oleh masyarakat muslim di Indonesia, maka penulis terpanggil untuk mengkaji dan membahas masalah ini, sehingga ada titik terang dan menjadi solusi at as problem yang sedang dihadapi. Masalah ini adalah masalah baru dan belum terjadi di masa nabi dan para salafus salih. Adapun rumusan masalah yang dikaji pada artikel ini, yaitu bagaimana hukum pelaksanaan salat Jumat dua gelombang di satu masjid di masa pandemi covid-19?.

Tujuan kajian ini adalah untuk mendeskripsikan pendapat para ulama tentang hukum salat Jumat dua gelombang di satu masjid pada masa pandemi Covid-19, dan menentukan pendapat yang kuat pada kedua masalah ini dengan beberapa argumen, dan juga bertujuan untuk merespon pertanyaan masyarakat tentang masalah ini agar ditemukan jawaban yang tepat, sehingga masyarakat dapat melaksanakan ibadah dengan tenang.

Metode yang digunakan dalam penelitian ini adalah metode kepustakaan (library research), yaitu menelusuri literatur-literatur primer dan sekunder yang berkaitan dengan kajian yang dibahas. Adapun jenis penelitian kajian ini adalah penelitian deskriptif kualitatif dengan menggunakan pendekatan normatif, yaitu mendeskripsikan perbedaan pendapat para ulama dan menentukan pendapat yang dianggap rajih (kuat) dalam masalah hukum pelaksanaan salat Jumat dua gelombang di satu masjid di masa pandemi Covid-19.

Adapun hasil kajian yang relevan dengan kajian ini di antaranya adalah hasil penelitian yang ditulis oleh Muh. Hamdan Fathur Rahim yang berjudul "Persepsi Tokoh Agama Tentang Shalat Jumat Di Dua Masjid Yang Berdekatan (Studi Kasus Desa Gilang Kec.Ngunut Kab.Tulungagung)". Tujuan dari kajian ini adalah untuk mengetahui persepsi tokoh agama tentang hukum salat Jumat di dua masjid yang berdekatan di desa Gilang-Tulungagung, dan untuk mendeskripsikan persepsi para ulama fikih tentang hukum salat Jumat di dua masjid yang berdekatan. Hasil dari penelitian ini menunjukkan bahwa: (1) Menurut persepsi tokoh masyarakat desa gilang tentang mendirikan salat Jumat di dua masjid yang berdekatan, adalah boleh dan salat Jumat di dua masjid tersebut sah, karena adanya hajat yakni antara kedua belah pihak tidak dapat dikumpulkan atau dipersatukan

Ronny Mahmuddin, Fadhlan Akbar, Iskandar. Hukum Pelaksanaan Salat... 
BUSTANUL FUQAHA: Jurnal Bidang Hukum Islam

Vol. 1, No. 3 (2020) : Hal. 350-365

Website: https://journal.stiba.ac.id

untuk mendirikan satu salat Jumat di dalam satu masjid; (2) Mayoritas ulama berpendapat pada dasarnya mendirikan salat Jumat di dua masjid yang berdekatan dalam satu desa secara bersamaan ( Ta'addud al-Jumah) hukumnya memang tidak diperbolehkan, apabila tidak ada uzur apapun yang menghalangi untuk dikerjakan dalam satu tempat (desa/kota). ${ }^{2}$

Kajian lain yang relevan dengan artikel ini adalah kajian yang diteliti oleh Eko Misbahuddin dan Muhammad Yusram dalam artikel jurnal yang berjudul “Hukum Salat Berjemaah di Masjid dengan Saf Terpisah Karena Wabah”. Tujuan dari kajian ini adalah mendeskripsikan hukum salat berjemaah dengan saf terpisah pada masa pandemi Covid-19. Hasil penelitian ini menunjukkan bahwa hukum salat berjemaah dengan saf renggang karena wabah adalah sah, namun mengikuti arahan pemerintah dan ulama (MUI) untuk salat di rumah adalah lebih diutamakan pada saat pandemi. ${ }^{3}$

Kajian lain yang relevan dengan kajian ini, adalah artikel jurnal yang berjudul "Darurat Moderasi Beragama di Tengah Pandemi Corona Virus Desease 2019 (Covid-19)" yang ditulis oleh Abdul Syatar, Muhammad Majdi Amiruddin dan Arif Rahman. Tujuan dari kajian ini adalah untuk mendeskripsikan urgensi menjaga moderasi beragama di masa pandemi. Hasil dari penelitian ini menunjukkan bahwa prioritas moderat beragama di masa pendemi Covid-19 menjadi suatu keharusan. ${ }^{4}$

Atas keseluruhan kajian di atas, pada dasarnya masih banyak lagi kajian yang relevan dengan kajian penulis ini, hanya saja yang membedakan dengan kajian penulis yakni belum adanya satu kajian yang mengupas tentang hukum salat Jumat dua gelombang di satu masjid di masa pandemi Covid-19, sehingga penulis memandang bahwa kajian ini adalah kajian yang baru dan layak untuk diteliti dan dibahas lebih mendalam.

\section{PEMBAHASAN}

\section{Hukum Pelaksanaan Salat Jumat Dua Gelombang di Satu Masjid di Masa Pandemi Covid-19}

Para ulama berbeda pendapat tentang hukum pelaksanaan salat Jumat dua gelombang di satu masjid di masa pandemi Covid-19. Ada di antara ulama yang tidak memperbolehkan, namun ada juga di antara ulama lainnya yang memperbolehkan. Ulama yang tidak memperbolehkan berlandaskan pada pendapat

${ }^{2}$ Lihat: Muh. Hamdan Fathur Rahim, "Persepsi Tokoh Agama Tentang Shalat Jumat Di Dua Masjid Yang Berdekatan (Studi Kasus Desa Gilang Kec.Ngunut Kab.Tulungagung)", Skripsi (Tulungagung: Jurusan Hukum Keluarga Islam, IAIN Tulungagung, 2019), h. 51-68.

${ }^{3}$ Lihat: Eko Misbahuddin Hasibuan dan Muhammad Yusram. (2020). "Hukum Salat Berjemaah di Masjid dengan Saf Terpisah Karena Wabah”. BUSTANUL FUQAHA: Jurnal Bidang Hukum Islam, Vol.1 No.2, h.106-124.

${ }^{4}$ Lihat: Abdul Syatar, dkk, (2020). "Darurat Moderasi Beragama di Tengah Pandemi Virus Corona 2019 (Covid19)". Kuriositas: Media Sosial dan Keagamaan. Vol. 13 No.1, h. 1-13. 
mereka yang tidak memperbolehkan pelaksanaan salat Jumat di beberapa tempat di satu kota dengan beberapa argumentasi atau hujah, yaitu tidak ada dalil yang menunjukkan kebolehan salat Jumat dua gelombang di satu masjid; adanya pembolehan akan menyebabkan dilaksanakannya salat Jumat dua gelombang tanpa hajat atau kebutuhan; dan adanya dua gelombang dilaksanakannya salat Jumat di satu masjid tidak sejalan dengan maksud pelaksanaan salat Jumat, yaitu berkumpulnya kaum muslimin di satu masjid dan di belakang satu imam.

Adapun ulama yang membolehkan dengan alasan bahwa jika tidak diperbolehkan melaksanakan salat Jumat dua gelombang di satu masjid, maka berakibat banyaknya kaum muslimin yang tidak melaksanakan salat Jumat, dikarenakan aturan yang diberlakukan di negara non muslim, kondisi masjid sempit dan tidak ada alternatif lainnya.

Berdasarkan perbedaan pendapat para ulama tentang masalah ini, maka penulis memilih pendapat bahwa hukum pelaksanaan salat Jumat dua kali atau dua gelombang di satu masjid, karena kondisi darurat atau kebutuhan mendesak adalah boleh. Jika dipaksakan seluruh jemaah melaksanakan salat Jumat satu gelombang atau satu kali saja di satu masjid yang mengakibatkan saf-saf salat menjadi rapat dan tidak ada jarak fisik (physical distancing), dikhawatirkan akan cepat terjadinya penularan virus Covid-19.

Oleh karena itu, dipandang perlu untuk melaksanakan salat Jumat dua kali atau dua gelombang di satu masjid demi mencegah kemudaratan yang lebih besar. Kebolehan pelaksanaan salat Jumat dua gelombang atau lebih, karena kondisi darurat atau kebutuhan yang mendesak berdasar pada dalil-dalil al-Quran, hadis, kaidah-kaidah fikih dan qiyas serta perkataan para ulama, seperti berikut ini:

\section{Landasan Dalil dari Al-Qur'an:}

1. Firman Allah swt. dalam QS. al-Baqarah/2: 185:

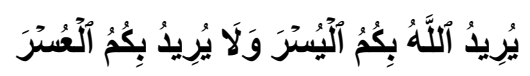

Terjemahan: "Allah menghendaki kemudahan bagimu, dan tidak menghendaki kesukaran bagimu."

2. Firman Allah swt. dalam QS. al-Baqarah/2: 286:

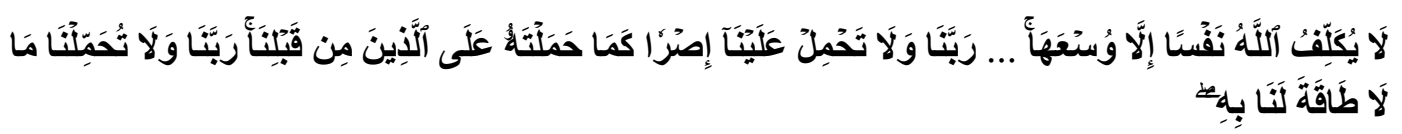

Terjemahan: "Allah tidak membebani seseorang melainkan sesuai dengan kesanggupannya..., Ya Tuhan kami, janganlah Engkau hukum kami jika kami lupa atau kami tersalah. Ya Tuhan kami, janganlah Engkau bebankan kepada kami 
BUSTANUL FUQAHA: Jurnal Bidang Hukum Islam

Vol. 1, No. 3 (2020) : Hal. 350-365

Website: https://journal.stiba.ac.id

beban yang berat sebagaimana Engkau bebankan kepada orang-orang sebelum kami. Ya Tuhan kami, janganlah Engkau pikulkan kepada kami apa yang tak sanggup kami memikulnya."

3. Firman Allah dalam QS. al-Nisā/4: 28:

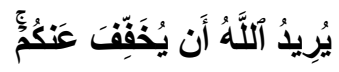

Terjemahan: "Allah hendak memberikan keringanan kepadamu."

4. Firman Allah dalam QS. al-Māidah/5: 6:

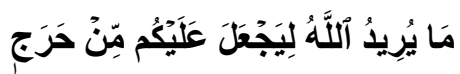

Terjemahan: “Allah tidak hendak menyulitkan kamu."

5. Firman Allah dalam QS. al-A'rāf/7: 157:

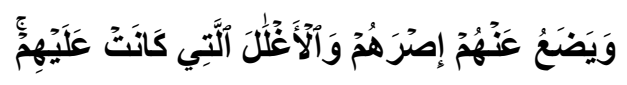

Terjemahan: "Dan (tugas nabi Muhammad) membuang dari mereka beban-beban dan belenggu-belenggu yang ada pada mereka."

6. Firman Allah dalam QS. al-Hajj/22: 78:

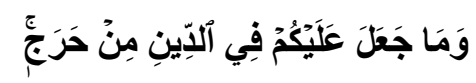

Terjemahan: "Dia (Allah) sekali-kali tidak menjadikan untuk kamu dalam agama suatu kesempitan."

7. Firman Allah dalam QS. al-An'ām/6: 119:

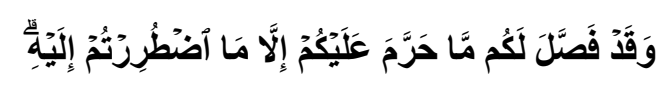

Terjemahan: "Dan sesungguhnya Allah telah menjelaskan kepada kamu apa yang diharamkan-Nya atasmu, kecuali apa yang terpaksa kamu memakannya."

8. Firman Allah dalam QS. al-Tagābun/64: 16:

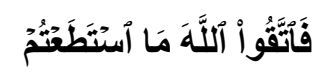

Terjemahan: "Maka bertakwalah kamu kepada Allah menurut kesanggupanmu."

Ayat-ayat di atas sangat jelas menunjukkan bahwa Allah menurunkan syariat Islam penuh dengan kemudahan dan tidak menyusahkan hamba-hamba- 
BUSTANUL FUQAHA: Jurnal Bidang Hukum Islam

Vol. 1, No. 3 (2020) : Hal. 350-365

Website: https://journal.stiba.ac.id

Nya, bahkan sesuatu yang diharamkan tatkala dalam kondisi darurat maka sesuatu yang diharamkan itu menjadi halal.

Oleh karena itu, pelaksanaan salat Jumat dua gelombang di satu masjid diperbolehkan jika darurat atau ada hajat yang mendesak berdasar pada ayat-ayat di atas.

\section{Landasan Dalil dari Hadis:}

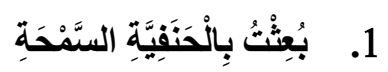

Terjemahan: "Saya diutus dengan membawa ajaran tauhid yang mudah."5

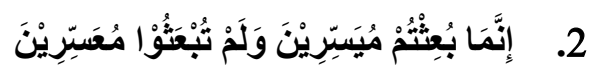

Terjemahan: "Sesungguhnya kalian diutus untuk memberikan kemudahan dan kalian tidak diutus untuk memberikan kesusahan kepada orang lain." 6

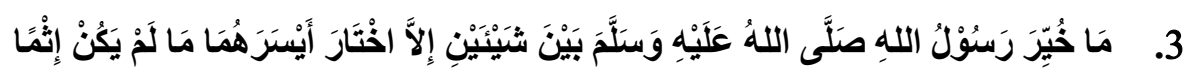

Terjemahan: "Tidaklah Rasulullah saw. diberikan dua pilihan, melainkan beliau memilih sesuatu yang paling mudah selama itu bukan perbuatan dosa." 7

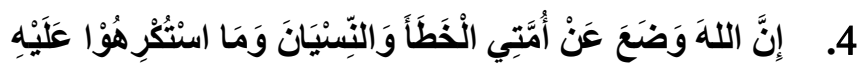

Terjemahan: "Sesungguhnya Allah menggugurkan dosa dari umatku yang melakukannya karena salah, lupa dan yang mereka dipaksa untuk melakukan (sesuatu yang diharamkan)." 8

Hadis-hadis di atas menunjukkan bahwa Islam yang dibawa oleh Rasulullah saw. adalah agama yang mudah dan tidak menyusahkan umatnya, apatah lagi jika ada hal-hal yang sifatnya darurat yang menyusahkan, maka Islam telah memberikan solusi.

Oleh karena itu, pelaksanaan salat Jumat dua gelombang di satu masjid karena darurat atau hajat mendesak, maka hukumnya boleh karena sejalan dengan hadis-hadis di atas.

\section{Landasan dari Kaidah-Kaidah Fikih:}

${ }^{5}$ Al-Imām Ahmad ibn Hanbal, Musnad al-Imām Ahmad ibn Hanbal, Vol. XXXVI (Cet. I; T.t: Muassasah alRisālah, 1421), h. 624.

${ }^{6}$ Muhammad ibn Ismā’̄il al-Bukhāriy, Sahīh al-Bukhāriy, Vol. I (Dar Tuq al-Najah, 1422), h. 54.

${ }^{7}$ Muslim bin al-Hajjāj al-Naisabūriy, Sahīh Muslim, Vol. IV (Bairut: Dār Ihyā al-Turas al-'Arabiy, t.th) , h. 1813.

${ }^{8}$ Muhammad ibn 'Abdillah al-Hākim al-Naisabūriy, al-Mustadarak 'alā Sahihain, Vol. II (Bairut: Dār al-Kutub al-'Ilmiyyah, 1411), h. 216. 
BUSTANUL FUQAHA: Jurnal Bidang Hukum Islam

Vol. 1, No. 3 (2020) : Hal. 350-365

Website: https://journal.stiba.ac.id

Là Darara walā Dirār. Maksud kaidah ini adalah seseorang tidak diperbolehkan memberikan mudarat kepada dirinya atau orang lain baik secara langsung atau tidak langsung (disengaja atau tidak disengaja). ${ }^{9}$ Berdasarkan analisis para ahli medis bahwa rapatnya saf-saf salat diprediksikan dapat memberikan kemudaratan meskipun tidak secara langsung yang menyebabkan cepatnya penularan virus Covid-19, sehingga kemudaratan ini harus dihindari dengan melakukan perenggangan saf-saf salat.

Oleh karena itu, adanya aturan perenggangan saf-saf salat bertujuan mencegah kemudaratan yang ditimbulkan baik langsung atau tidak secara langsung, yaitu menyebarnya virus. Dengan adanya perenggangan saf-saf salat sehingga salat Jumat dua kali dilaksanakan di satu masjid, itu dilakukan lantaran melihat kondisi masjid yang tidak dapat menampung jemaah yang begitu banyak jika dilaksanakan di satu waktu dalam keadaan saf-saf yang rapat.

Al-Masyaqqah Tajlibu al-Taisĩr. Kaidah ini menunjukkan bahwa tatkala seseorang menemukan kesusahan maka kesusahan itu menjadi sebab kemudahan, ${ }^{10}$ seperti seseorang yang sakit yang tidak bisa terkena air, maka dibolehkan baginya untuk tidak berwudu dan diganti dengan tayamum. Hal ini juga bisa dikiaskan atau disamakan dengan bolehnya pelaksanaan salat Jumat dua kali di satu masjid melihat kondisi penyebaran Covid-19 yang begitu cepat tatkala saf-saf salat dirapatkan.

Oleh karena itu, perlunya perenggangan saf shalat meskipun berdampak pada pelaksanaan salat Jumat dilaksanakan dua kali di satu masjid guna mencegah penyebaran covid.

Dar'u al-Mafásid Muqaddam 'alā Jalbi al-Mașālih. Kaidah ini menunjukkan bahwa mencegah kemudaratan lebih didahulukan daripada mendapatkan kemaslahatan. ${ }^{11}$ Pelaksanaan salat Jumat satu kali di satu masjid dalam keadaan saf-saf salat yang rapat bisa memberikan kemudaratan, yakni cepatnya penularan virus Covid-19, meskipun pada dasarnya saf-saf yang rapat dalam salat berjemaah adalah suatu kebaikan dan perkara yang diperintahkan. Oleh kerena besarnya mudarat yang ditimbulkan jika salat Jumat dilaksanakan dalam keadaan saf-saf yang rapat, maka kemudaratan ini harus dicegah dengan tidak merapatkan saf salat.

Oleh karena itu, dibolehkan pelaksanaan salat Jumat dua kali di satu masjid karena darurat atau hajat yang mendesak berdasar pada kaidah "Dar'u al-Mafäsid Muqaddam 'alā Jalbi al-Mașālih".

${ }^{9}$ Lihat: Muhammad Sidqiy ibn Ahmad al-Burnū, al-Wajīz fi I ̣̦āh al-Qawāid al-Fiqhiyyah al-Kulliyyah (Cet.V; Bairut: Muassasah al-Risālah, 1419/1998), h. 251.

${ }^{10}$ Lihat: Muhammad Sidqiy ibn Ahmad al-Burnū, al-Wajīz fi I⿳亠̄ăh al-Qawāid al-Fiqhiyyah al-Kulliyyah, h. 218 dan 'Abdullah ibn Salih al-Fauzan, Syarhu Jam'u al-Maḥșūl fi Syarhi Risālah ibn Sa'diy fi al-Ușūl (Cet. I; Riyad: Dar alMuslim, 1424), h. 105.

${ }^{11}$ Lihat: Muhammad Ṣidqiy ibn Ahmad al-Burnū, al-Wajīz fi Iọāh al-Qawāid al-Fiqhiyyah al-Kulliyyah, h. 265. 
BUSTANUL FUQAHA: Jurnal Bidang Hukum Islam

Vol. 1, No. 3 (2020) : Hal. 350-365

Website: https://journal.stiba.ac.id

Al-Ḍarūrāt Tubīhu al-Mahzürāt. Kaidah ini menunjukkan bahwa perkaraperkara yang diharamkan jika dalam keadaan darurat, maka diperbolehkan untuk dilakukan. ${ }^{12}$ Hukum asal salat Jumat dilaksanakan hanya satu kali di satu masjid, namun karena ada sesuatu yang darurat yaitu dikhawatirkan cepatnya penularan virus Covid-19 jika dilaksanakan satu kali di satu masjid dengan kondisi saf-saf yang rapat, maka kondisi darurat itu membolehkan sesuatu yang diharamkan, yaitu pelaksanaan salat Jumat dua kali di satu masjid.

Oleh karena itu, pelaksanaan salat Jumat dua gelombang di satu masjid karena darurat atau hajat maka dibolehkan berdasar pada kaidah "al-parürät Tubīhu al-Mahzūūāt.

Al-Maisūr Lā Yasqut bi al-Ma'sūr. Kaidah ini menunjukkan bahwa sesuatu yang masih bisa dikerjakan oleh seseorang, maka tidak boleh ditinggalkan hanya karena ada kesusahan. ${ }^{13}$ Berkaitan dengan pelaksanaan salat Jumat di saat pandemik Covid-19, maka salat Jumat tidak dibolehkan unt uk ditinggalkan selama salat tersebut bisa dikerjakan sesuai kemampuan seseorang, yaitu salat dalam keadaan saf direnggangkan yang berakibat dilaksanakannya salat Jumat dua kali (dua gelombang) di satu masjid, karena kondisi masjid yang tidak bisa menampung seluruh jemaah dalam satu waktu, kecuali jika pemerintah dan ulama mengeluarkan aturan untuk menutup masjid sementara waktu melihat kondisi Covid-19 yang tidak terkendali, maka pada saat itu tidak diperkenankan menyelisihi aturan pemerintah dan ulama demi menjaga persatuan dan kesatuan kaum muslimin, sebagaimana kaidah fikih berbunyi: "Hukmu al-Hākim fii Masāil al-Ijtihād Yarfa'u al-Khiläf,"l4 artinya: "Keputusan pemerintah menyelesaikan perbedaan pendapat di tengah umat." Salat Jumat dalam kondisi tersebut harus tetap dikerjakan meskipun ada kesusahan yang dihadapi, yakni kondisi Covid-19 meskipun salat Jumat harus dilaksanakan dua kali di satu masjid.

Oleh karena itu, pelaksanaan salat Jumat dua gelombang di wilayah yang penyebaran covidnya terkendali sebagaimana arahan pemerintah dan ulama selama bisa dilaksanakan karena darurat atau hajat yang mendesak, maka hukumnya boleh berdasar pada kaidah fikih “al-Maisūr Lā Yasqut bi al-Ma'sūr. Berdasar pada kaidah ini seseorang tidak diperbolehkan meninggalkan salat Jumat selama masih ada kemudahan untuk melaksanakannya meskipun ada sedikit kendala/kesusahan, yaitu salat Jumat dua kali di satu masjid dengan merenggangkan saf salat.

\footnotetext{
${ }^{12}$ Lihat: Muhammad Șidqiy ibn Ahmad al-Burnū, al-Wajīz fi Tựāh al-Qawāid al-Fiqhiyyah al-Kulliyyah, h. 234

${ }^{13}$ Lihat: Muhammad Sidqiy ibn Ahmad al-Burnū, al-Wajīz fi İ̃āh al-Qawāid al-Fiqhiyyah al-Kulliyyah, h. 396

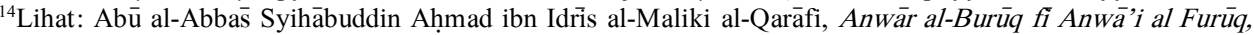
Vol. II (Kuwait: Dār al-Nawādir, 1431), h. 103.
} 
BUSTANUL FUQAHA: Jurnal Bidang Hukum Islam

Vol. 1, No. 3 (2020) : Hal. 350-365

Website: https://journal.stiba.ac.id

İ̇ā Dāàa al-Amru Ittasa'. Kaidah ini menunjukkan bahwa apabila seseorang menemukan kesulitan karena suatu sebab darurat, maka diberikan kemudahan baginya untuk melakukan sesuatu yang diharamkan. ${ }^{15}$ Berkaitan dengan pelaksanaan salat Jumat dua gelombang di satu masjid karena darurat atau kebutuhan yang mendesak, maka diperbolehkan, meskipun pada asalnya tidak boleh dua kali dilaksanakan salat Jumat di satu masjid tanpa sebab darurat, namun karena kondisi darurat, maka diperbolehkan.

Oleh karena itu, pelaksanaan salat Jumat dua gelombang karena darurat atau hajat yang mendesak diperbolehkan berdasar pada kaidah fikih: İā Dáqa alAmru Ittasa' (Apabila suatu urusan itu sempit karena darurat, maka urusan tersebut menjadi luas) ${ }^{16}$.

Là wājiba Ma'a al-‘Ajz wa Là Muharram Ma'a al-Darürat. Kaidah ini menunjukkan bahwa syariat Islam tidak mewajibkan kepada kita selama kita tidak bisa mengerjakannya secara keseluruhan, dan perbuatan wajib yang diperintahkan kepada seseorang, namun ia tidak sanggup melakukannya, maka tidak ada kewajiban baginya. ${ }^{17}$

Berdasarkan kaidah ini, maka pelaksanaan salat Jumat dua kali (dua gelombang) di satu masjid diperbolehkan di masa pandemik Covid-19 ini, karena untuk melaksanakan hanya satu kali dalam satu waktu tidak bisa dilakukan karena masjid sempit tidak bisa menampung semua jemaah karena saf salat harus direnggangkan dan tidak ada alternatif lain, sehingga yang seharusnya dilaksanakan hanya satu kali di satu masjid menjadi gugur karena ada uzur.

Al-Hājah Tunazzal Manzilah al-Ḍarūrāt 'Ammah Kānat aw Khāṣsah. Kaidah ini menunjukkan bahwa hajat (kebutuhan) kadang diposisikan sama dengan sesuatu yang darurat baik secara umum atau khusus. ${ }^{18}$ Berkaitan dengan pelaksanaan salat Jumat dua gelombang at au lebih di satu masjid karena kebutuhan mendesak, yakni untuk menghindari kerumunan jemaah tanpa adanya jarak fisik demi menghindari cepatnya penyebaran virus Covid-19, maka kondisi tersebut dianggap sama dengan kondisi darurat sehingga hukumnya sama dengan hukum darurat, yaitu dibolehkan sesuatu yang diharamkan karena kondisi darurat.

Oleh karena itu, pelaksanaan salat Jumat dua gelombang atau lebih di satu masjid karena hajat mendesak, maka dibolehkan berdasar pada kaidah fikih "alHājah Tunazzal Manzilah al-Ḍarūrāt 'Ammah Kānat aw Khāṣ̦ah.

${ }^{15}$ Lihat: Muhammad Sidqiy ibn Ahmad al-Burnū, al-Wajīz fị Iḍāh al-Qawāid al-Fiqhiyyah al-Kulliyyah, h. 230.

${ }^{16}$ Lihat: 'Abd al-Wahāb ibn Taqiyuddin al-Subkiy, al-Asybah wa al-Nazāir, Vol. 1 (Cet.I; Bairut: Dar al-Kutub al-'Ilmiyyah, 1411), h. 48 dan 'Abd al-Rahmān ibn Abū Bakr a-Suyuțiy, al-Asybah wa al-Nazāir fị Qawāid wa Furū' alSyāfí'iyyah (Cet. I; Bairūt: Dār al-Kutub al-'Ilmiyyah, 1403), h. 83.

${ }^{17}$ Lihat: 'Abdullāh ibn Șālih al-Fauzān, Syarhu Jam'u al-Mạ̣sūl fi Syarhi Risālah ibn Sa'diy fi al-Ușūl, h. 107.

${ }^{18}$ Lihat: Muhammad Sidqiy ibn Ahmad al-Burnu, al-Wajiz fi Iọāh al-Qawāid al-Fiqhiyyah al-Kulliyyah, h. 242. 
BUSTANUL FUQAHA: Jurnal Bidang Hukum Islam

Vol. 1, No. 3 (2020) : Hal. 350-365

Website: https://journal.stiba.ac.id

\section{Landasan dengan Menggunakan Qiyas}

Pelaksanan salat Jumat dua gelombang atau lebih di satu masjid karena ada hajat mendesak diperbolehkan berdasarkan qiyas, yaitu di-qiyas-kan atau disamakan dengan bolehnya salat Jumat dilaksanakan di berbagai tempat di satu daerah atau kota. Ulama Kuwait dalam situs $w W w$.islamweb.net ${ }^{19}$ menyebutkan, bahwa jumhur ulama membolehkan pelaksanaan salat Jumat di beberapa tempat jika jarak masjid jauh, atau masjid sempit, atau takut terhadap gangguan atau uzur lainnya.

Ibn Bāz menyebutkan satu riwayat bahwa 'Ali ibn Abi Țālib pada masa kekhalifaannya pernah ditanya bahwa di kota Kufah ada orang-orang lemah yang susah bagi mereka untuk keluar melaksankan salat Id berjemaah di sahara (padang pasir), maka beliau memerintahkan seseorang menjadi imam untuk dilaksankan salat Id di dalam kota bersama orang-orang yang lemah. Adapun 'Ali bin Abi Ṭālib melaksanakan salat Id bersama kaum musliminin di padang pasir.

Jika pelaksanaan salat Id dibolehkan di dua tempat pada zaman 'Ali ibn Abī Țālib karena ada hajat mendesak, maka pelaksanaan salat Jumat di dua tempat di satu kota atau daerah sama kondisinya dengan dibolehkannya salat Id di dua tempat, karena adanya kesulitan, hajat yang mendesak dan untuk memberikan kemudahan bagi kaum muslimin. Jumhur ulama membolehkan pelaksanaan salat Jumat di beberapa tempat karena adanya hajat yang mendesak. ${ }^{20}$

Ibn Qudāmah dalam al-Mugniy mengatakan bahwa salat Jumat disyariatkan untuk berkumpul dan mendengar khotbah, maka dibolehkan untuk dilaksanakan di beberapa tempat jika dibutuhkan seperti pelaksanaan salat Id. Telah sahih adanya riwayat bahwa 'Ali ibn Abì Ṭālib pada masa khilafah beliau melaksanakan salat Id di padang pasir (sahara) dan meminta Abu Mas'ūd al-Badriy untuk menjadi imam salat Id bagi kaum muslimin yang lemah yang tidak sanggup mendatangi tempat salat Id di padang sahara. Adapun Nabi Muhammad saw. tidak melaksanakan salat Jumat dua kali di satu masjid, karena para sahabat ingin sekali melaksanakan salat Jumat bersama nabi dan ingin mendengar nasehat-nasehat beliau, karena beliau adalah rasul Allah yang bertugas menyampaikan risalah dan hukum Allah, meskipun rumah-rumah mereka jauh dari masjid nabi. Adapun jika tidak ada hajat mendesak, maka tidak diperbolehkan salat Jumat dilaksanakan di berbagai tempat. Jumhur ulama mengatakan bahwa nabi dan para sahabatnya tidak pernah diriwayatkan, bahwa mereka melaksanakan salat Jumat di dua tempat atau lebih, karena pada saat itu belum ada hajat yang mendesak. ${ }^{21}$ h. $351-355$

${ }^{19}$ Lihat: https://www.islamweb.net/ar/fatwa/23537/ (diakses 30 Mei 2020).

${ }^{20}$ Lihat: ‘Abd al-'Azīz ibn Bāz, Majmū' Fatāwā wa Maqālāt Mutanawwi’ah (Cet. II; Riyad: Dār al-Ișda, 1421),

${ }^{21}$ Lihat: Muaffaquddin 'Abdullāh ibn Aḥmad ibn Qudāmah al-Maqdisiy, al-Mugniy, Vol. II (t.c; Mesir: Maktabah Qāhirah, 1388), h. 248. 
Berdasarkan pernyataan di atas menunjukkan, bahwa hukum dibolehkannya pelaksanakan salat Jumat dua kali di satu masjid, karena hajat sama hukumnya dengan dibolehkannya pelaksanaan salat Jumat di beberapa tempat di sebuah daerah atau wilayah karena hajat.

Disebutkan dalam situs islamweb.net, ${ }^{22}$ bahwa melaksanakan salat Jumat di dua tempat di satu kota atau daerah adalah perkara yang belum terjadi di zaman sahabat nabi saw. Taqiyuddin al-Subkiy mengatakan dalam kitabnya al-Fatawa, bahwa maksud dari pelaksanaan salat Jumat adalah agar seluruh kaum mukminin dapat berkumpul dan memperoleh wejangan dan nasehat. Paling sempurna pelaksanaannya jika dilaksanakan di satu tempat karena mereka semua berkumpul dan agar terjalin persaudaraan di antara mereka. Lebih lanjut al-Subkiy mengatakan bahwa ada tiga tujuan dilaksanakannya salat Jumat, yaitu menampakkan syiar Islam, memperoleh nasehat dan mempersatukan hati-hati kaum mukminin sehingga mereka saling menyayangi dan saling mencintai.

'Abd al-Razzāq meriwayatkan dari Ibn Juraij mengatakan, bahwa saya pernah bertanya kepada 'Athā' (seorang tabi'in): "Bagaimana pendapat Anda, masjid raya di Basrah tidak bisa menampung semua penduduk Basrah, apa yang mesti mereka lakukan?" Ațā' menjawab: "Setiap kaum yang memiliki masjid, mereka boleh melaksanakan salat Jumat di masing-masing masjid mereka."

Ibn 'Ābidin (ulama Hanafiyah) dalam kitabnya Rad al-Muhtār berkata: "Salat Jumat boleh dilaksanakan di beberapa tempat di satu kota tanpa syarat". Disebutkan dalam kitab al-Inshaf. "Tidak boleh dilaksanakan salat Jumat lebih dari satu tempat jika tidak ada hajat." Mazhab Malikiyah, Syafi'iyah dan Hanabilah, dan riwayat Hanafiyahyang kuat, bahwa tidak boleh dilaksanakan salat Jumat lebih dari satu tempat jika tidak ada hajat atau kebutuhan.

Lajnah Dāimah (Komite Fatwa Ulama Besar Saudi Arabia) dalam situs www.islamweb.net mengeluarkan fatwa bahwa pelaksanaan salat Jumat dua kali di satu masjid tidak dibenarkan secara syariat. Kami tidak mengetahui hal ini ada asalnya di dalam Agama Islam. Pada asalnya salat Jumat dilaksanakan satu kali di satu kota, tidak diperkenankan pelaksanaan salat Jumat lebih dari satu tempat, kecuali jika ada uzur syar'i seperti jauhnya jarak tempat tinggal dari masjid atau masjid sempit sehingga tidak bisa menampung semua jemaah atau uzur lainnya yang dibolehkan untuk melakukan salat Jumat di tempat lain. ${ }^{23}$

Disebutkan dalam situs islamonline.net, bahwa pelaksanaan salat Jumat dua gelombang di satu masjid karena ada hajat seperti masjid yang tidak bisa menampung semua jemaah, maka ini adalah hajat yang diperbolehkan bahkan termasuk darurat khususnya pada saat musim yang sangat dingin. Telah terdapat

\footnotetext{
${ }^{22}$ Lihat: https://www.islamweb.net/ar/fatwa/23537/ (diakses 30 Mei 2020).

${ }^{23}$ Lihat: https://www.islamweb.net/ar/fatwa/23537/ (diakses 30 Mei 2020).
} 
dalil bahwa 'Amr bin al-'Ash pernah junub pada satu perjalanan, namun beliau tidak mandi janabah dan memimpin salat berjemaah dalam keadaan bertayamum, maka pasukannya melaporkan peristiwa ini kepada Rasulullah saw. 'Amr bin al'Ās pun menjawab: "Ya Rasulullah, pada malam itu cuaca sangat dingin dan saya teringat firman Allah yang berbunyi: "Janganlah kalian membunuh diri-diri kalian, sesungguhnya Allah Maha Penyayang atas kalian". Nabi pun tersenyum." (HR. Abu Dawūd dan al-Dāraqutniy).

Dalil di atas menunjukkan bahwa cuaca yang sangat dingin termasuk sebab-sebab keringanan dan kemudahan. Allah tidak memerintahkan manusia untuk memudaratkan atau membunuh diri-diri mereka. Nabi bersabda: "Tidak boleh memberikan mudarat kepada diri sendiri (orang lain) baik sengaja atau tidak sengaja." 24

Ahmad Khalil dalam almoslim.net menyebutkan bahwa pelaksanaan dua kali salat Jumat di satu masjid hukum asalnya tidak boleh karena bertentangan dengan maksud pelaksanaan salat Jumat, yaitu persatuan kaum muslimin, untuk mendengarkan wejangan dan nasehat serta penampakan syiar Islam. Di antara kaidah fikih bahwa syarat salat yang lebih besar dari salat Jumat yang mesti dilakukan di satu masjid bisa gugur pada kondisi jika ada uzur seperti seseorang yang tidak bisa melakukan taharah (bersuci). Siapa yang tidak bisa mengerjakan syarat sahnya salat seperti taharah, maka gugurnya syarat pelaksanaan salat Jumat hanya satu kali di satu masjid adalah lebih pantas jika ada uzur. Ibn Qayyim berkata: "Di antara kaidah syariat bahwa tidak ada sesuatu yang diwajibkan jika ada uzur, dan tidak ada keharaman jika kondisi darurat."25

Berdasarkan pernyataan-pernyataan para ulama di atas, maka diperbolehkan pelaksanaan salat Jumat dua kali atau dua gelombang di satu masjid, karena darurat atau hajat yang mendesak seperti masjid sempit dan tidak ada halaman yang memadai sehingga tidak bisa menampung jemaah dalam satu waktu karena mengharuskan perenggangan saf-saf salat pada saat kondisi Covid19 sekarang ini. Hal ini disamakan dengan kebolehan pelaksanaan salat Jumat di berbagai tempat karena hajat yang kuat atau mendesak berdasar pada pendapat jumhur ulama. Bahkan ada sebagian ulama memperbolehkan pelaksanaan salat Jumat di berbagai tempat di satu kota/desa meskipun tidak ada hajat yang kuat atau mendesak. Namun, pendapat jumhur ulama yang lebih kuat.

Penulis memilih dibolehkannya salat Jumat dua gelombang di satu masjid dengan beberapa syarat, yaitu sebagai berikut:

\footnotetext{
${ }^{24}$ Lihat: https://fatwa.islamonline.net/1084 (diakses 30 Mei 2020).

${ }^{25}$ Lihat: http://almoslim.net/node/234000 (diakses 30 Mei 2020).
} 
Syarat Pertama: Salat Jumat dengan dua gelombang harus dilaksanakan pada wakt unya, yaitu dari tergelincirnya matahari (masuknya waktu zuhur) hingga sebelum masuk waktu salat Asar.

Syarat Kedua: Dilaksanakan jika ada kebutuhan mendesak atau darurat seperti masjid kecil dan tidak ada halaman atau jalan yang memadai, dan tidak ada masjid atau tempat alternatif lain untuk dijadikan tempat salat.

Syarat Ketiga: Banyaknya jumlah jemaah di gelombang kedua sebagaimana banyaknya jumlah jemaah di gelombang pertama.

Syarat Keempat. Mendapatkan izin dari pemerintah.

\section{KESIMPULAN}

Penulis menutup pembahasan ini dengan memberikan kesimpulan, bahwa para ulama berbeda pendapat tentang hukum pelaksanaan salat Jumat dua gelombang di satu masjid, antara yang membolehkan dan yang tidak membolehkan. Adapun pendapat yang penulis pilih adalah dibolehkannya melaksanakan salat Jumat dua gelombang atau lebih di satu masjid di masa pandemi Covid-19 dengan beberapa syarat yaitu: (1) Kondisi darurat atau hajat yang mendesak seperti kondisi sekarang di mana menyebarnya virus Covid-19 sehingga pengaturan saf-saf salat harus direnggangkan untuk mencegah penularan lewat kontak fisik yang berakibat masjid tidak cukup menampung jemaah dalam satu waktu; (2) Salat Jumat dengan dua gelombang harus dilaksanakan pada waktunya; yaitu dari tergelincirnya matahari (masuknya waktu zuhur) hingga sebelum masuk waktu salat Asar; (3) Banyaknya jumlah jemaah di gelombang kedua sebagaimana banyaknya jumlah jemaah di gelombang pertama; dan (4) Mendapat izin dari pemerintah.

Namun, jika masjid tersebut besar dan memiliki halaman yang luas dan layak untuk digunakan sebagai tempat salat, sehingga dapat menampung semua jemaah yang hadir, maka tidak diperbolehkan melaksanakan salat Jumat dua gelombang, karena masjid dan halamannya masih bisa menampung semua jemaah. Berkaitan dengan imam dan khatib salat Jumat, jika dilaksanakan dua gelombang salat Jumat di satu masjid, maka imam dan khatib salat Jumat di gelombang pertama bisa sama imam dan khatibnya di gelombang kedua, meskipun yang utama jika imam dan khatibnya di gelombang pertama berbeda dengan imam dan khatibnya di gelombang kedua.

\section{DAFTAR PUSTAKA}

Al-Quran dan Terjemahnya.

Al-Bukhāriy, Muhammad ibn Ismā’ìl. (1422 H). Sahīh al-Bukhāriy, Vol. I. Dar Tuq alNajah. 
BUSTANUL FUQAHA: Jurnal Bidang Hukum Islam

Vol. 1, No. 3 (2020) : Hal. 350-365

Website: https://journal.stiba.ac.id

Al-Burnū, Muḥammad Șidqiy ibn Ađ̄mad. (1998). al-Wajīz fi I⿳̣̄āh al-Qawāid al-

Fiqhiyyah al-Kulliyyah. Cet.V; Bairut: Muassasah al-Risālah.

Al-Fauzān, 'Abdullāh ibn Șālih. (1424 H). Jam'u al-Maḥsūl fi Syarhi Risālah ibn Sa'diy fi al-Ușūl . Cet. I; Riyad: Dar al-Muslim.

Al-Maqdisy, Muaffaquddin 'Abdullāh ibn Aḥmad ibn Qudāmah. al-Mugniy, (1388 H). Vol. II. t.c; Mesir: Maktabah Qāhirah.

Al-Naisaburiy, Muhammad ibn 'Abdillah al-Hākim al-Naisabūriy. $(1411$ H). alMustadarak 'alā Sahīhain. Vol. II. Bairut: Dār al-Kutub al-'Ilmiyyah.

Al-Naisābūriy, Muslim ibn al-Hajjāj. (t.th). Sahīh Muslim, Vol. IV. Bairut: Dār Ihyā alTuras al-"Arabiy.

Al-Subkiy, Abd al-Wahāb ibn Taqiyuddīn. (1411 H). al-Asybah wa al-Nazāir, Vol. 1.

Cet.I: Bairut: Dar al-Kutub al-'Ilmiyyah.

Al-Suyutịy 'Abd al-Raḥmān ibn Abū Bakr. (1403 H). al-Asybah wa al-Nazāir fī Qawāid wa Furū' al-Syāfi'iyyah. Cet. I; Bairūt: Dār al-Kutub al-'Ilmiyyah.

Al-Qarāfi, Abū al-Abbas̄ Syihābuddin Aḥmad ibn Idrīs al-Maliki. (1431 H), Anwār alBurūq fí Anwā'i al Furūq, Vol. II. Kuwait: Dar al-Nawadir.

Ibn Hanbal, al-Imām Ahmmad. Musnad al-Imām Ahmad ibn Hanbal. (1421 H). Vol. XXXVI. Cet. I; t.t: Muassasah al-Risālah.

Ibn Bāz, 'Abd al-'Azīz ibn 'Abdullāh. (1421 H). Majmū' Fatāwā wa Maqāiāt Mutanawwi’ah. Cet. II; Riyāẹ: Dār al-Iṣ̣̣ā.

Misbahuddin, Eko Hasibuan dan Muhammad Yusram. (2020). "Hukum Salat Berjemaah di Masjid dengan Saf Terpisah Karena Wabah". BUSTANUL FUQAHA: Jurnal Bidang Hukum Islam. Vol.1 No 2.

Rahim, Muh. Hamdan Fathur. (2019). 'Persepsi Tokoh Agama Tentang Shalat Jumat Di Dua Masjid Yang Berdekatan (Studi Kasus Desa Gilang Kec.Ngunut Kab.Tulungagung)", Skripsi. Tulungagung: Jurusan Hukum Keluarga Islam, IAIN Tulungagung.

Syatar, Abdul, dkk, (2020). "Darurat Moderasi Beragama di Tengah Pandemi Virus Corona 2019 (Covid-19)". Kuriositas: Media Sosial dan Keagamaan. Vol. 13 No.1, h. 1-13.

\section{Dari Internet.}

https://www.islamweb.net/ar/fatwa/23537/

https://www.islamqa.info/ar/answers/260538/

https://Www.islamway.net / fatwa/9258/

https://WwW.islamonline.net./1084.

https://WwW.almoslim.net/node/234000 